\title{
INTRODUCTION: THE SECOND BERLUSCONI GOVERNMENT
}

\author{
Jean Blondel and Paolo Segatti
}

The year 2002 was expected to be an epoch-making year for Italian politics. It was to be the first occasion to gauge whether things had really changed since the "First Republic." Between the end of that "classical" regime in the early 1990s and the year 2001, some aspects of politics had indeed altered, but the depth and durability of the move to a new type of behavior was still at best uncertain. Polarization between right and left had occurred, with the center squeezed in between. That was new, at least ostensibly, but the shape that governments were taking did not provide clear signs of transformation. On the one hand, much had been transitional, as with the several "technical" or "semi-technical" cabinets. On the other hand, much was old hat: a center-right "majoritarian" coalition had fallen after only six months in 1994-not a good omen for the stability of the "new" politics. Developments during the 1996-2001 legislature reflected even more a sense of déjà vu. With the president of the republic refusing to dissolve Parliament, preferring instead to see the victor of the 1996 election, Romano Prodi-a leader without a party at his disposal, to be sure-defeated by his own side, two other prime ministers (and three cabinets) followed each other in less than three years. This scarcely was in keeping with the goals of the "new" politics.

With the election of the spring of 2001, on the other hand, a sea change seemed to have taken place: the coalition led by Silvio 
Berlusconi (the Casa delle Libertà) had a clear majority. Admittedly, Berlusconi's party, Forza Italia, did not have an absolute majority on its own, even if it towered in numerical strength over the several elements of that coalition-Alleanza Nazionale, the Lega Nord, and the two small centrist groups, the CCD and the CDU (which later joined to form the UDC). ${ }^{1}$ Remarkably, however, and probably for the first time in the history of the Italian Republic —or at least since Alcide De Gasperi disappeared from the scene in the early 1950s (with the possible exception of Bettino Craxi's role, for a while, in the 1980s, an exception that had left sour memories) - the signs indicated that there was to be strong governmental leadership, a characteristic that had been sorely missing in Italian national politics. The truly novel phenomenon was that the new prime minister had won the election because of his popularity. A kind of preliminary rehearsal of that development had occurred during the 1994 election, as a result of which Berlusconi became prime minister for the first time. However, his coalition had not won a clear majority, nor had the depth of his support among the population been truly tested, his party being at the time still very new and, in the eyes of many, likely to be purely transient. Indeed, the ground lacked solidity, as seemed evident when the government fell after a mere seven months in office, ostensibly the result of what came to be regarded as the "betrayal" of the Lega. A similar fate was not expected to occur during the lifetime of the 2001 Parliament. On the contrary, after the election, which proved that Berlusconi's party had successfully overcome five years in opposition, everyone assumed that the government would be in office for the duration.

Despite this universally made prediction, things already seemed to be going badly around Christmas 2001, as if a repeat of the 1994 experience were taking place. The government (mainly the minister of finance) appeared to want to fight quixotic battles against the euro, which was coming into use at the time, and the minister of foreign affairs resigned on the grounds that he was not fully supported by his colleagues. These were not good signs of potential longevity for a cabinet that had completed only its first six months. Yet the government did survive: there was to be no "betrayal" by the Lega or by anybody else. Berlusconi patched up differences by taking over the foreign affairs post-allegedly for six months, in fact for somewhat longer-but a better curtain raising for 2002 was needed if the rest of the play was to be a success.

If the program of the Casa delle Libertà was to be believed, that play was to have many important themes. There was the theme of decentralization, variously described as devolution or federalism. 
There was the theme of the liberation of the economy from the state in order to enable entrepreneurs to act. There was the associated theme of social change, from pensions to social security. There was the theme-expressed more often after the government came to power than before- of a more active and independent foreign policy. There was also what might be called the undercurrent theme of the reform of the judiciary, a theme that was discussed only obliquely by the new majority, as so much seemed connected to the position of the prime minister himself, but was repeated, almost ad nauseam, by the opposition. There was indeed the other undercurrent theme of the reform of the institutional structure of the executive, which had been tried unsuccessfully in the previous legislature and which has never been totally absent from the agenda of Italian politics, old or new. If the government was to be an active, no-nonsense cabinet, it had to tackle these themes during the legislature, and some of the work at least had to be undertaken in 2002. How these themes would be played in the first full year in office was unquestionably fundamental for the standing of the government in public opinion. But these themes also had to be played successfully if Italian politics was to take a new direction.

To achieve such goals, the style and the substance of the decisionmaking process were equally critical. Of course, the substance of governmental action was essential: Forza Italia and its allies had promised that there would be long overdue reforms, in order to give Italy and the Italians the deal that they deserved. Yet the Casa delle Libertà had also implied that there was to be an end to the "games" that had taken place before 1992 but which seemed to reappear as soon as Romano Prodi was forced to leave office. Prime ministers followed one after the other, while governments seemed once more not to have direct links with the population. Thus, both substance and style had to be noticeably different if voters were to be convinced that politics had indeed changed.

\section{Has the Style of Italian Politics Truly Changed?}

Let us begin by examining the changes that may have taken place with respect to the style of politics, based on the evidence of 2002 . Style has many components of which policy within the cabinet and the actions of the prime minister constitute important elements. With respect to the government, the key question was whether, despite the fact that Italy was still to be ruled by a coalition, members of the cabinet would now be more united than their predecessors had been. 
With respect to the prime minister, the question that needed to be answered was whether he would lead, perhaps even dominate, the cabinet, whether he would be forceful in putting forward his policies. To use Brian Farrell's well-known expression, would the prime minister be a "chief" rather than a "chairman"?

Yet cabinet members are not the only actors who contribute to forging the political style of a nation. Parliamentarians are obviously important players. Would the "new" style mean that there would be a decline in the ability of members of the two chambers to undo or markedly amend what the government had proposed? Would the legislature's capacity to control legislation thus come to be as limited as it is in other Western European countries? Going beyond Parliament, one needs to discover how the members of the opposition at large would adapt to the "new majoritarian" structure. In particular, would they speak with one voice when attacking the government? Finally, would the president of the republic decide to be only an "umpire"? Would he fully dissociate himself from the substance of the "game" and see that his role was to ensure that no one acted against the proper rules? All of these actors contribute to determining the political style of a nation and must therefore be described and analyzed if an accurate picture is to be drawn of the style of Italian politics in 2002 .

The role of the president of the republic must be examined with care in the context of such a new juncture. This is what Gianfranco Pasquino undertakes in his chapter on President Carlo Azeglio Ciampi. The task is most difficult, partly because the president cannot-must not-state openly what his goals are, partly because the situation with which Ciampi was faced was entirely novel, and partly because, in the particular context in which the president found himself, the figure of the prime minister was clearly controversial. Silvio Berlusconi is no Tony Blair or Gerhard Schroeder; his past career resembles more that of Thaksin Shinawatra of Thailand, who was in fact elected prime minister only a few months earlier, at the end of 2000, in somewhat similar circumstances. Given these problems, one could expect the president to be subjected-mainly behind the scenes, but perhaps also in the open-to pressures from those who wanted him to be a player rather than an umpire. His predecessor, Oscar Luigi Scalfaro, had been tempted more than once to take an active posture. If Ciampi resisted the temptation to intervene, would he not likely be considered by part-or perhaps by much-of the opposition as acting as a player for the "other side"?

These are the elements of the equation that Gianfranco Pasquino weighs with subtlety. One can start from the recognition that, unlike his predecessor, Ciampi benefited from the prestige he had acquired 
as prime minister and perhaps even more as minister of finance in the Prodi government. His election to the presidency on a near-unanimous basis was both a proof of this prestige and an asset that would enable him to enjoy some freedom of action. Indeed, throughout the year, he exercised marked restraint; as Gianfranco Pasquino notes, Ciampi decided to place great emphasis on the unity of the nation within the European context. Perhaps as a result, apart from very few cases in which members of some organizations requested an audience to discuss matters that generated great tension, he has not been, openly at least, asked to intervene in conflicts between the government and the opposition. He pointedly chose to approve the legislation adopted by the governmental majority, even when the opposition considered such legislation as highly controversial or unacceptable. A crucial test is still to come if the government loses its majority in one or the other of the Chambers of Parliament. The president would then have to decide either to dissolve Parliament or, as his predecessor did in 1995, to select a prime minister who would govern with a different majority, even though that prime minister would not have clear popular support. While the question did not arise in 2002, such a hypothesis cannot be ruled out as wholly academic.

Perhaps the problems faced by the president of the republic turned out to be less acute than they might otherwise have been because of the major divisions-amounting almost to a fracture-within the opposition. In his chapter, James Newell details six key grounds on which to assess the character of an opposition: its leadership, its boundaries, its linkage with outside groups, its willingness to cede "sovereignty" to an organ acting in the name of the whole opposition, its ability to develop a united program, and, finally, its commitment to sharing a long-term strategy. On all six counts he finds the current Italian opposition wanting. Basically, even if one leaves aside Rifondazione Comunista, which was outside the coalition during the 2001 election and for that reason has been accused of enabling the Casa delle Libertà to win, the opposition is so sharply divided that one cannot see in what way it can constitute a true challenge to the government.

Granted, the non-governmental parties made significant gains at the local elections in the spring of 2002, as Gianfranco Baldini and Guido Legnante show in their chapter, which is also largely devoted to the specific characteristics of Italian local politics and in particular to the part that leadership plays at that level-in contrast to the limited part it has played, traditionally at least, at the national level. Indeed, the fact that local politicians often exercise leadership in their "bailiwick" is perhaps part of the problem, as it tends to account for the fact that conflicts can be sharp on the national stage. There is a 
chasm between the Left Democrats (mainly composed of ex-Communists) and the Margherita (mainly composed of ex-Christian Democracy elements but internally divided, in large part on personality grounds). Moreover, within these two groupings there is a certain nostalgia for a proportional system that reflects diverse strategic evaluations of the nature of the center-left coalition. Within the Margherita, a version of this nostalgia for a proportional electoral system sometimes emerges as the desire for a party to incorporate the center from each of the two major political groupings, center-right and center-left. There are thus almost two oppositions rather than one. They may not have to co-exist locally, as in many cases only one of the two elements predominates at that level, but they do have to co-exist and confront each other at the national level.

This is why it is difficult to see-at this point, at any rate-how the opposition can genuinely unite behind a single leader, even if it is in the rather low-key manner in which the center-left did so during the 2001 election. The national situation thus resembles the one that prevailed in Britain in the 1980s when a faction of the Labour Party split to form the SDP and the non-Conservative parties were rendered powerless against Margaret Thatcher. Deep down, the fact that the Margherita's electoral strength was almost equal to that of the Left Democrats in 2001 makes the choice of a strong joint leader almost impossible: neither side is prepared to concede. Not surprisingly, no progress in this respect was made in 2002. As a matter of fact, there was perhaps regression, not just because of occasionally sharp divisions on policy (for instance, on foreign affairs as well as immigration) between the two main branches of the opposition, but because the border between those "centrists" who support the government and those who do not is, to say the least, rather fluid.

Such a state of affairs would seem to make it rather easy for the government to rule decisively. Yet, to continue the comparison with Britain, it emerged in the course of 2002 (indeed, some evidence was already being accumulated in 2001) that Silvio Berlusconi was no Margaret Thatcher and that the cabinet was neither truly united nor consequently able to make decisions speedily and forcefully. Meanwhile, perhaps as a result, the government does not appear to be able to exercise full control over the decisions of Parliament.

Admittedly, unlike Margaret Thatcher, Silvio Berlusconi is not the head of a cabinet of a single party enjoying an absolute majority in Parliament. He runs a coalition of five parties. At least two of theseAlleanza Nazionale and the Lega-have opposite views about the nature and role of the state in general and of the Italian state in particular. The Lega is in the government on sufferance, largely because 
it was electorally weak at the 2001 election; yet the Lega cannot altogether abandon the "federalist" (if not "secessionist") principles on which it has been based. Nor can it show great sympathy for immigrants from outside the European Union.

These problems were known from the start: they could have been examined in detail at the time of the discussion of the pre-election agreement among the parties belonging to the center-right. While they may have been considered at that point, whatever consideration was then given to them must have been somewhat superficial. Nor did it seem that the problems were studied in any serious manner when the government was formed after the election. As a matter of fact, perhaps the greatest problem lies elsewhere: the way the prime minister runs his cabinet does not suggest that he is actively involved in either the process leading to the elaboration of policies or in the substance of the solutions proposed. From this point of view, the decision to personally take on certain ministerial posts, such as that of minister of foreign affairs, is, as Filippo Andreatta and Elisabetta Brighi assert, more a sign of the difficulty of governing a divided coalition than of real leadership capacity. A similar conclusion may be drawn regarding the prime minister's decision to help the minister of public works in his task. It is interesting to note that both of these decisions involved technical ministries rather than political ones.

As a result, as Maurizio Cotta and Luca Verzichelli point out in their chapter, the impression that emerges is that Silvio Berlusconi's rule is not different in kind and character from that of manyindeed, most-prime ministers of the "First Republic." There seems to have been, on a variety of issues, as is shown in the contribution to this volume devoted to the detailed examination of the substance of governmental policies, a prevailing climate of uncertainty among members of the government as to what line was to be followed. Major delays have occurred as a result, both before draft bills came to the council of ministers for approval and when they were presented to Parliament.

Throughout the negotiations that had to take place in this context, the prime minister seems to have been involved only to a limited extent. Granted, he has been careful to see to it that conflicts did not arise to such a level that the cabinet's survival might be endangered: hence, the periodic meetings that he has had with the leaders of the two parties most likely to feel frustrated by the direction policies might take. He has been manifestly successful in calming any impatience that the Lega might have had as a result of the slow pace of the devolution process. Meanwhile, on the substance of the decisions, the prime minister does not appear to wish to make a definite 
mark. He may be influential behind the scenes, but little evidence has emerged showing him to be decisive, let alone indicating that he has been following a "master plan." Systematic empirical analysis will have to be undertaken to assess the extent of the contribution of the prime minister to the content of policies during the period: subject to what such analyses will show, the prevailing impression is that the prime minister chairs but does not really lead the cabinet.

The role of the whole Berlusconi government in policy-making, if not that of the prime minister alone, can at least be assessed in relation to the part that Parliament is "allowed" to play in this context. Since World War II, the Italian Parliament, unlike the parliaments of other Western European countries, has tended to be regarded as strong and has thus resembled the U.S. Congress in terms of the influence, often negative, which it has had on the policy process. For decades, however, one of the grounds for this strength of Parliament was assumed to be the need to involve the Communist Party with legislation at a time when it was politically impossible to allow representatives of that party to sit in the government. This ground disappeared with the end of the Cold War, and one might therefore have expected the Italian Parliament to lose at least part of the influence that it had previously acquired in favor of the government. This was indeed what began to occur during the transition period, at a time when the whole party system was in disarray.

Such a trend could have been expected to be reinforced with the coming of the Casa delle Libertà to power in 2001. Yet the evidence of executive-legislative relations in 2002 suggests that little has taken place in that direction. To begin with, as Giliberto Capano and Marco Giuliani note in their chapter, one must not exaggerate the strength of the Italian Parliament even under the "First Republic," let alone during the transition period. The widespread use by governments of the decree-making procedure enabled the executive to by-pass Parliament in many cases, in effect, with the tacit approval of the legislature. These decrees, in principle, had to be approved by Parliament within two months if they were to remain in force, but they were often simply periodically reissued before lapsing. This practice was ruled unconstitutional by the Constitutional Court during the transition period, but whether that decision has had a significant impact on Parliament's influence on the policy process is difficult to assess. As Giliberto Capano and Marco Giuliani suggest, the direct result seems more to have been a decline since 2001 in the legislative activity of the government itself. Meanwhile, there is little evidence that Parliament has become less influential since the Berlusconi government came to power. A comprehensive examination of the votes that 
took place in the Chamber of Deputies, reported in the essay, shows that the proportion of cases in which majorities of 80 percent or more approved pieces of legislation continues to be almost as large as it was previously. This analysis reinforces the impression, which emerges in connection with some of the major government bills and in particular with the budget, that the government is prepared to make (or has to make) major concessions in order to be successful. Executive-legislative relations do not seem to have changed markedly with the advent of the center-right majority government.

It is perhaps too early to claim that the style of national Italian politics continues to be based on efforts to achieve a degree of consensus rather than on a desire to exercise strong leadership, whether on the part of the government as a whole or on that of the prime minister. Indeed, such a conclusion would seem to contradict the view that there is a high level of conflict in political relationships, as reported, for instance, in the media: conflict at this level seems inconsistent with the relatively low-key leadership and the rather slow policymaking process that has characterized the Berlusconi government since it took power in the middle of 2001. Yet perhaps this combination is also inherited from the past: the "First Republic" was also characterized by a high level of tension combined with limited leadership and relative inefficiency at the policy-making level. In this respect, too, there may not be as much change as might have been expected from the results of the 2001 election, but before coming to such a conclusion, one needs to analyze some of the key policy developments that have taken place-as well as some of the developments that have not taken place-in the course of 2002 .

\section{Has the Substance of Policy-Making Changed?}

A few years ago, Maurizio Cotta observed that the variation of party government that characterized the "First Republic" consisted of a long cycle during which the average policies, aimed at "the modification of important aspects of the economic, social, foreign and institutional policies" of the country, ${ }^{3}$ were subject to a degree to competition between government action and political parties. In electoral terms, the party-political system seemed to favor competition between the meta-political decisions regarding "the definition of the basic order of the political regime, of the political community or of the socio-economic system," 4 while in terms of governmental action, it seemed to favor the search for consensus, often of a "transversal" kind, regarding choices and policies that got mixed up with the micro-safeguarding of 
the electoral clientele. Of course, it would be wrong to suppose that this aspect did not alter during the long life of the "First Republic": as far as competition over meta-policies is concerned, there was a slow process of change as democracy gradually consolidated itself. On the other hand, there were undoubtedly moments of strong pressures for reform, which Maurizio Cotta sees as coinciding with the initial stages of the various political formulas characterizing Italian political life up until the 1990s.

On the whole, however, the distinguishing feature of the Italian variety of party government was the weakness of government action in the field of intermediate-level policy. The reason for this was probably the fundamental flaw of the post-war political system, namely, the impossibility of alternating governmental power. On the one hand, this guaranteed the major parties a kind of unearned electoral income based on competition between interests modeled by metapolitical choices made during the early years of the Italian political system. On the other hand, it compromised the value of any comparison of the parties at the intermediate policy level.

In recent years, however, and for the first time since the end of World War II, this limitation no longer exists. The last two general elections have seen the alternating of two party coalitions that were very different in terms of their political color and party program. In particular, the 2001 election was characterized by two events that marked a significant break with the past. The center-right coalition managed to defeat a government in office, taking advantage of the voters' marked disappointment with the latter's policies. The election winners presented themselves to the voters as the advocates of a new start based on a strict adherence to their electoral platform (the contract with the Italian people), while continuing to describe their opponents as the heirs to the old "partitocracy." It would appear, therefore, that the premises have been established for a cycle of radical innovation in intermediate-level policies, a season of reforms free from the stale ideologies of old and from traditional political nepotism, even though the winners' insistence on calling their opponents the heirs to "partitocracy" clearly indicate that there was some danger of relapsing ideologies. After more than a year, can we safely say that this risk has been avoided and a new policy-making cycle has begun? The essays contained in the present volume provide a series of different answers to this question.

Filippo Andreatta and Elisabetta Brighi, in their reconstruction of the second Berlusconi government's foreign policy, describe an ambivalent situation in which features from the past co-exist with newer aspects. On the one hand, the Berlusconi government's foreign 
policy has been continually characterized by the deep division among the various parties making up the Casa delle Libertà coalition-and within the coalition's main party itself-over the question of Europe. Such conflicts in the sphere of foreign policy often originate from considerations and calculations of domestic policy. There is nothing really new about this, although past divisions over foreign policy involved clashes between government parties and opposition parties and were of comparatively less importance within government ranks. However, the real novelty is the solution adopted by the coalition leader in order to manage these conflicts: he chose to personalize the management of foreign policy. ${ }^{5}$ Andreatta and Brighi show how this choice, while it may have shielded the government from intra-coalition differences and tension, has led to an erratic management of the foreign policy agenda, thus putting at risk the country's image as a trustworthy partner.

David Nelken provides a detailed analysis of the development of the stormy relationship between the center-right majority, the judiciary, and the opposition on the question of justice. During the course of 2002, a number of laws were passed that may (euphemistically) be considered to be examples of micro-policies, that is, measures designed to satisfy the expectations of small groups but which, according to an almost universal interpretation, really aimed at protecting specific individuals from possible judicial problems, including the prime minister and a number of his associates. The nature of these laws and the zeal with which they were pushed through Parliament led to disapproval within some sectors of the opposition and reinforced existing doubts about the government majority's democratic credentials. The word "reinforced" is used since for years the question of justice has been part of a wider conflict over legitimacy. The same wide-ranging reforms of the judicial system announced by the minister of justice-the reform of the High Council of the Judiciary (Csm) electoral system, the proposed reform of judicial committees and of the Constitutional Court itself, and the repeated proposals for the separation of the careers of investigating magistrates and judges-have been perceived as a day of reckoning for some sections of the judiciary accused of having pursued political objectives in the past.

All of this inevitably led to an indignant reaction from members of the judiciary, and the ensuing acrimonious debate often simply exacerbated the spiral of reciprocal delegitimization. "Each side," Nelken observes in his chapter, "therefore came to see its own legitimacy as depending on undoing the prestige of the other.... The result was a 'zero sum' game." Overall, the substance of policy-making has once 
again been characterized by a strong ideological drift typical of metapolicies. Within this context, those topics that proved difficult to politicize, such as the urgent need for more administrative personnel within the judicial system, have gradually disappeared from the sphere of public debate, despite their importance in rendering the Italian judicial system more efficient—an objective shared by all parties.

A slightly different viewpoint is offered by Paolo Onofri's analysis of the orientation given to economic policy by the Berlusconi government in 2002. During the course of 2001, and to an even greater degree in 2002, economic policy choices were adopted that clearly indicate the political desire to make a clean break from the achievements of the previous center-left governments. In fact, Onofri sees the Berlusconi government's prime political objective as being that of "marking a complete break with the past." In Onofri's view, the passage from electoral promises (tax reductions, increased pensions, and public spending on infrastructures, together with a reduction in the public sector deficit) to economic policy provisions is nevertheless full of pitfalls that could prove insuperable in the end. The international economic situation, together with the temporary character of a number of financial measures, could make the long-term management of the public sector deficit a rather precarious task. However, it remains to be seen whether the Berlusconi government, in an attempt to pursue a different path to growth from that formulated by the center-left government, is in fact trying to maintain its electoral pledges. At the end of the day, this expectation represents the key to democratic representation, but there is obviously no guarantee that the economic policy pursued by the Berlusconi government will be successful or in the best interests of the country.

A profound change from the choices made by governments during the previous parliamentary term can also be seen with regard to the so-called bank foundations, as Renzo Costi's detailed analysis makes abundantly clear. The previous governments had given the foundations private status, and had clearly defined the terms by which the separation between the banks and the foundations controlling them was to take place. On both counts, the Berlusconi government has intervened with great determination, reintroducing provisions of a public character within the banks' statutes and envisaging forms of control over the banks that could indefinitely postpone any separation of the banks from the foundations. This question has yet to be resolved, but the Berlusconi government's plan is clear: it is to bring the bank foundations once again under political control, mainly through local authorities, and (perhaps) re-create conditions for a political management of credit. 
Thus, the Berlusconi government has attempted to implement a program of reform designed to constitute a clean break with the recent past, a program that reflects the political priorities of its coalition and the populist vocation of the majority of its members. At the same time, however, the overall profile of this operation cannot be said to be new. On the contrary, it brings to mind an earlier tendency to extend the influence of politics over institutions that could (or should) govern themselves according to non-political principles. This was the practice of that variety of party government which in everyday language was referred to as "partitocracy."

Neither is it a novelty that fierce trade union conflict should explode from time to time in Italy. The conflict over the reform of article 18 was undoubtedly one of the strongest yet seen, and the failure to reform the article in 2002 was a bizarre outcome. Despite the fact that the idea of an overall reform of the rules governing individual dismissals, which aimed at greater flexibility, had been on the legislators' agenda for some time and had been at the center of negotiations between unions and employers, from the very start the decisional process regarding the reform of article 18 veered away from the merits of the question to the defense of the various players' ideological standpoints. As Aris Accornero and Eliana Como explain, this skirting of the issue itself dates back to 1999, when the nation was called upon to vote on a series of referenda proposed by the Radical Party (Partito radicale). The multitude of referenda included two particularly burning issues: one was the proposed abolition of article 18, promoted by the Confederation of Italian Industry (Confindustria), while the other concerned the funding of trade unions. The trade unions-in particular, the CGIL trade union-saw these referenda as a challenge to their identity and role, even though the outcome of the referenda was rendered invalid as the proportion of voters was below 50 percent.

The government turned its attention once more to the question of the reform of article 18 at the beginning of 2002. From the very start, it appeared to want to separate that reform from the more general question of the labor market reform, almost as if the former of the two questions was the more important. Moreover, some ministers and observers expressed the view that the practice of consulting with the unions and the employers' associations should be dropped. In a situation of growing tension, the Red Brigades reappeared on the scene, with the murder of the law professor and government consultant Marco Biagi. After this event, the government suddenly rediscovered the value of "social dialogue" and began discussions with those trade union organizations willing to do so. The result was the 
formulation of the "Pact for Italy," of which the reform of article 18 was only part.

Thus, the proposed reform of article 18 has had a troubled life, without achieving its objective, given not only that it has disappeared from the government's agenda, but also that it was defined as being politically irrelevant by the prime minister himself during his end-ofyear press conference. The story of the failure to reform article 18 clearly illustrates two rather common aspects of Italian policy-making. On the one hand, there is the ease with which problems even of a relatively technical nature are turned into a theme of public discourse, designed to create and preserve an identity. On the other hand, there is the government's uncertainty as to which path to take, namely, whether to move toward an ideological conflict or not.

The government appears to suffer from a similar uncertainty over the immigration law. This was a central theme of the center-right's electoral campaign. Even a proportion of the center-left voters were prepared to acknowledge that the center-right was better able to deal effectively with the problem. ${ }^{6}$ Asher Colombo and Giuseppe Sciortino's analysis of the Bossi-Fini law and of its legislative passage, however, probes the complex picture, which is characterized by propaganda, by the inability to formulate a legislative framework designed to reduce the discretionary powers of the bureaucracy, by paradoxical results (the largest-ever act of regularization of illegal immigrants ever seen in Italy), by somewhat modest legislative changes, and by the underestimation of the financial cost of the new measures. In the end, the one aspect of the Bossi-Fini law that has remained closest to the initial contents of the government's electoral platform is the connection between the immigrant's residence permit and his or her employment contract, on the basis of the rather utopian notion that Third World immigration at the beginning of this new millennium can be dealt with effectively by assuming that it is a temporary and reversible phenomenon. The gap between the contents of the law and electoral promises results from the limited agreement among the various components of the Casa delle Libertà, and from the opposition expressed by important constituencies, such as the Catholic sector. The center-right government is thus facing major difficulties in translating its vast electoral support into policy consent among important sectors of the community involved in the problem.

Silvio Berlusconi said that the year 2003 would be the year of reform. The overall picture provided by studies of a number of policies implemented by the government in 2002 constitutes perhaps a preview of what future reforms will tend to be. In a sense, the 2002 
picture reveals elements inherited from the past-foreign policy divisions, the propensity of the "new political class" to reappropriate some "partitocratic" prerogatives, the tendency to frame burning issues such as the nature of the judicial system in a way that they become even more contentious, with the result that each side is delegitimated. In another sense, the government has proved itself unable, as with the Bossi-Fini law, to build the necessary consensus for its policies toward the immigration issue. In the case of the reform of article 18, the government could not (or did not want to) go all the way with the plans its voters had endorsed. There have been three genuine innovations so far: legislation passed speedily to safeguard individual interests; Berlusconi's decision to personalize the management of foreign policy as a way to handle conflicts within the centerright coalition; and the determination with which the whole government wished to implement the economic promises made during the electoral campaign. There are worries about the outcome of the first two innovations; even the third could cause difficulties, as there is no guarantee that actions made in response to voters' expectations will be responsible.

The year 2002 was not only the year in which the second Berlusconi government had the opportunity and time to reveal its policymaking style, it was also the year in which Italy's most important manufacturer, Fiat, suffered a major crisis. Giuseppe Berta's reading of that crisis goes beyond a mere description of Fiat's market difficulties: it shows how, in contrast to past crises, Fiat failed to formulate "an approach to relations with political power, the trade unions, and public opinion limited to overcoming its own difficulties." The difficulties of the last remaining great Italian manufacturer do not appear to be merely the result of weak internal leadership, but also seem due to the fact that the political and industrial scene changed significantly in recent years. Weak internal leadership together with a modified environment have combined to complicate the formulation of a strategy capable of saving what could be saved. In Berta's analysis of the Fiat crisis, one remark in particular calls for reflection: "The players in the company's crisis, partly victims and partly makers of an interactive dynamics that rules out any strategic rationality, behave in an opportunistic, selfinterested manner." When seen from this perspective, the Fiat crisis seems both to epitomize the difficulties of the country and to indicate the possible reasons for this state of affairs. The crisis of Italian industry is therefore perhaps perceived by observers as a significant aspect of the country's decline. 


\section{Conclusion}

The second Berlusconi government, like the first, has been seen by Italian and foreign observers to be a serious deviation from both the Western democratic tradition and from Italy's own democratic tradition. The story of a business magnate with vast interests in all sectors of the economy who comes to govern the country despite serious problems with the law courts raises many questions about the consequences for the quality of democracy. Yet the picture that emerges from the essays contained in this volume is more complex. Apart from the conflict of interest and the unresolved judicial problems, the behavior of the Berlusconi government, both of its members individually and of the prime minister, on the basis of what was achieved in 2002, reveals defects that are inherent in Italian democracy.

Some of these are connected to the institutional organization of government and to the link between the cabinet and Parliament, as a result of which strong leadership can not be exercised, a defect that is aggravated by the fact that the government continues to be based on heterogeneous coalitions. Other defects in the choices made so far relate to the political culture and habits of Italian politicians, both past and present-habits such as the inclination to frame each issue in terms of a clash of ideologies and to adopt a populist vision of democracy, together with the government's inability to translate electoral support into support for specific reforms. While the former defects could be reduced by institutional reforms, no reform seems able to redress the defect resulting from the governing class's being steeped in populist culture and inclined toward a kind of public discourse in which the question of safeguarding one's identity prevails over the formulation and implementation of policies.

Leaving aside the conflict of interest and judicial problems faced by Berlusconi, the achievements of his government in 2002 differ only in degree, not in kind, from typical Italian democratic behavior. This is scarcely a good omen. In the past, Italy managed to "survive without governing," to use Giuseppe Di Palma's expression. Can the country repeat such a performance in a markedly more complex international environment, both within and outside the European Union? 


\section{Notes}

1. To which the center group Democrazia Europea, led by Sergio D’Antoni, can be associated.

2. Brian Farrell, Chairman or Chief (Dublin: Gill and Macmillan, 1971).

3. Maurizio Cotta, "La crisi del governo di partito all'italiana," in Il Gigante dai piedi di argilla, ed. Maurizio Cotta and Pierangelo Isernia (Bologna: Il Mulino, 1996), 29.

4. Ibid.

5. The idea of this double role is not new, but what is new is the highly personal way Berlusconi has interpreted these roles.

6. See the figures from the post-electoral survey conducted by ITANES in ITANES, Perché ha vinto il centro-destra (Bologna: Il Mulino, 2001), and also Paolo Bellucci, "L'elettore che ragiona," in Le ragioni dell'elettore, ed. M. Caciagli and P. Corbetta (Bologna: Il Mulino, 2003). 
